\title{
DOI https://doi.org/10.30525/978-9934-26-179-4-34
}

\section{КОРУПЦЙНН РИЗИКИ ПІД ЧАС ВЧИНЕННЯ МИТНИХ ПРОЦЕДУР}

\author{
Савенкова В. Г. \\ кандидат юридичних наук, \\ заступник директора з наукової роботи \\ Приватний вищчй навчальний заклад «Фінансово-правовий коледж» \\ м. Київ, Украӥна \\ Лисенко I. I. \\ студентка III курсу ОКР «Молодший спеціаліст» \\ спеціальності 072 «Фінанси. Банківська справа та страхування» \\ Приватний вищий навчальний заклад «Фінансово-правовий коледж» \\ м. Київ, Украӥна
}

Прояви корупції в Україні залишаються одними 3 актуальних та топових проблем для громадян країни та суспільства в цілому. Корупція загрожує економічній безпеці держави, знижує ефективність iii функціонування та створює загрозу безпеці громадян та суспільства. За дослідженнями громадської думки, презентованого КМІС на замовлення USAID, протягом останніх років толерантність до корупції зменшується. Натомість кожен третій опитаний готовий приєднатись до усвідомленої протидії корупції в Україні [1]. Явище корупції (в усіх iї проявах) є загрозою для успішного розвитку української економіки, порушує питання соціальної забезпеченості населення, а також має реальний вплив на співробітництво України 3 міжнародними партнерами. На думку дослідників, саме корупція є основною загрозою економічній безпеці України при вступі до Європейського Союзу.

Науковою базою дослідження стали праці провідних вітчизняних та зарубіжних вчених, таких як: Д. О. Олійника, О.О. Макухіна, А.В. Ліпенцева, О.С. Войтик, Н.Г. Мазій, У. Минта та ін. Нормативною базою дослідження стали: Закон України «Про запобігання корупції» [3], Кримінальний кодекс України, висновок Венеціанської Комісії Ради Європи щодо Закону України «Про запобігання корупції», Кримінальна конвенція про боротьбу з корупцією від 27 січня 1999 р., Конвенція Організації Об'єднаних Націй проти корупції від 31 жовтня 2003 р., Цивільна конвенція про боротьбу з корупцією від 04 листопада 1999 р.

Відповідно до ст.1 ЗУ «Про запобігання корупції» дане явище трактується як використання особами, уповноважених на виконання 
функцій держави або місцевого самоврядування, наданих їм службових повноважень чи пов'язаних $з$ ними можливостей з метою одержання неправомірної вигоди або прийняття такої вигоди чи прийняття обіцянки/пропозиції такої вигоди для себе чи інших осіб або відповідно обіцянка/пропозиція чи надання неправомірної вигоди особі або на іiі вимогу іншим фізичним чи юридичним особам з метою схилити цю особу до протиправного використання наданих їй службових повноважень чи пов'язаних з ними можливостей [3]. О.О. Макухін розглядає декілька підходів до аналізу сутності корупції. У найбільш загальному розумінні корупція є синонімом до слів «хабар», «підкуп» та продажності посадових осіб [4]. У. Минт трактує дане поняття як використання державним службовцем свого статусу, повноважень, службового становища для задоволення власних потреб. Також він окреслює, що до корупційних дій належать: хабарництво, вимагання, шахрайство, розкрадання, кумівство, привласнення державного майна та активів для приватного використання та торгівля владними повноваженнями [5]. Станом на початок 2021 р. Україна посідає 117 місце зі 180 країн у списку Corruption Perceptions Index (CPI) за рівнем сприйняття корупції [6].

Громадяни та суб'єкти господарювання стикаються в певній мірі 3 корупцією в кожній сфері діяльності. Дана проблематика існує і у сфері здійснення митних процедур. Корупція під час здійснення митних процедур, в свою чергу, заподіює шкоду фінансовій, продовольчій, екологічній безпеці України, перешкоджає розвитку зовнішньоекономічної діяльності та партнерів держави по торгівельним відносинам [7]. Під корупційними злочинами в сфері здійснення митних процедур розуміється сукупність злочинів, що вчиняється посадовими особами митних органів у зв'язку з виконанням митних формальностей 3 метою отримання неправомірної вигоди. Спираючись на данні Свропейської Бізнес Асоціації (СБА) станом на 2018 р., а саме дослідження «Митний індекс» - 35,6\% респондентів стверджують, що не задоволені якістю митних послуг та професіоналізмом працівників митних органів, а 58,6\% переконані, що корупція на українському митному кордоні залишається на рівні 2017 р. [8, с.2]. У зв'язку 3 корупційними діями у митній сфері, наша держава щорічно втрачає близько 4 мільярдів євро. Про це свідчить розслідування німецького видавництва Süddeutsche Zeitung [9, с.2]. Також про втрати через корупцію та контрабандне перевезення на митному кордоні України наголошує міністр фінансів С. М. Марченко. Згідно з його словами, держава недоотримує до 2-3 млрд. грн. на місяць [10]. 
Дослідники стверджують, що корупція на митному кордоні збільшує частку тіньової економіки. Відповідно спостерігаємо зростання показників тіньової економіки у січні-березні 2020 року до 30\% від обсягу офіційного ВВП, що на 3 в.П. менше за показник січня-березня 2019 року. $[11$, ст. 2]. Основними проблемами, які необхідно вирішити на шляху подолання корупції в Україні $\epsilon$ належна якість та коректність законодавства. Згідно з аналітичним звітом Центру політико-правових реформ, виділяються наступні прояви такої недосконалості: заплутаність та розпорошеність регулювання в різних нормативно-правових актах, надмірна абстрактність законів; суперечність між положеннями різних нормативно - правових актів; застарілість багатьох актів законодавства; відсутність регулювання ієрархії нормативно правових актів [12, ст. 21-24]. В рамках даної проблематики Державною митною службою України у межах визначеної законодавством компетенції, здійснюються заходи, спрямовані на профілактику проявів корупції, запобігання втягуванню посадових осіб митних органів у протиправну діяльність. За результатами 2020 року працівники Державної митної служби виявили порушень митних правил на 2,6 млрд. грн, розглянуто 4 тис. справ про порушення митних правил, виписано штрафів на 178,4 млн. грн. До суду передано 11 тис. справ на суму майже 2,4 млрд. грн. Кількість переданих справ порівняно з 2019 роком збільшилась майже на $30 \%$, судами накладено стягнень на суму майже 1,2 млрд. грн. і цей показник на 34\% більший за показник 2019 року [13].

Отже, аналізуючи вищевикладене, можна стверджувати, що проблематика корупції в Україні $є$ багатогранною. Відсутність уніфікованого підходу та інструментарію дослідження проблем корупції, а також єдиного аналітичного центру щодо вивчення передумов та стану корупції знижує ефективність антикорупційної політики держави. Для зменшення ризиків вчинення корупційних злочинів, необхідно запровадити комплексний підхід у вдосконаленні законодавства, запровадити кращі закордонні практики попередження корупційних ризиків, реформувати сферу митного контролю та запровадити якісно новий підхід до боротьби з проявами корупції у всіх сферах суспільного життя.

\section{Література:}

1. Фонд Демократичні ініціативи імені Ілька Кучеріва : веб-сайт. URL : https://dif.org.ua/article/kozhna-tretya-ukrainkaets-gotovi-doluchitisyado-organizovanoi-protidii-koruptsii (дата звернення 05.12.2021).

2. Корупційні ризики надання адміністративних послуг та контрольно-наглядової діяльності в Україні: Аналітичний звіт підготовлено Центром політико - правових реформ. Соціологічний звіт 
підготовлено Фондом «Демократичні ініціативи» : веб-сайт. URL: https://rm.coe.int/16806еeae4 (дата звернення 05.12.2021).

3. Про запобігання корупції: Закон України від 14 жов. 2014 р. Дата оновлення 17.11.2021 p. № 49 URL : https://zakon.rada.gov.ua/laws/ show/1700-18\#Text.

4. Макухін О.О. Поняття корупції в Україні та СС: порівняльний аналіз, адміністративно-правовий аспект. Вчені записки Таврищького наиіонального університету ім. В.І. Вернадського. Серія «Юридичні науки». Том 26 (65). 2013. № 2 - 1 (Ч. 2). с. 55-61. URL: https://cyberleninka. $\mathrm{ru} /$ article/n/ponyattya-koruptsiyi-v-ukrayini-ta-es-porivnyalniy-analizadministrativno-pravoviy-aspekt/viewer (дата звернення 15.12.2021).

5. U Myint Corruption: causes, consequences and cures. Asia-Pacific Development Journal Vol. 7, No. 2, December 2000. URL: https://www.unescap.org/sites/default/d8files/apdj-7-2-2-Myint.pdf (дата звернення 14.12.2021).

6. Transparency international Ukraine. Індекс сприйняття корупиії2020 : веб-сайт. URL : http://cpi.ti-ukraine.org/\#/ (дата звернення 10.12.2021).

7. Олійник Д.О. Запобігання корупційним злочинам, що вчиняються при здійсненні митних процедур : монографія / за наук. ред. Б. М. Головкіна. Харків : Право, 2018. 200 c. URL : http://criminology.nlu. edu.ua/wp-content/uploads/2018/03/mono_olijnik_2018.pdf_(дата звернення 19.12.2021).

8. Митний індекс 2018 : веб-сайт Свропейської Бізнес Асоціації. URL : https://eba.com.ua/yevropejska-biznes-asotsiatsiya-oprylyudnylarezultaty-mytnogo-indeksu/ (дата звернення 10.12.2021).

9. Süddeutsche Zeitung Ukraine : веб-сайт. URL: https://www. sueddeutsche.de/thema/Ukraine (дата звернення 10.12.2021).

10. Financial club Україна щомісяця втрачає до 3 млрд грн через корупцію на митниці : веб-сайт Financial club. URL : https://finclub.net/ ua/news/ukraina-shchomisiatsia-vtrachaie-do-3-mlrd-hrn-cherez-koruptsiiuna-mytnytsi-marchenko.html (дата звернення 10.12.2021).

11. Міністерство економіки України. Тенденції тіньової економіки: веб-сайт. URL : https://me.gov.ua/Documents/List?lang=uk-UA\&id= e384c5a7-6533-4ab6-b56f-50e5243eb15a\&tag=TendentsiiTinovoiEkonomiki (дата звернення 10.12.2021) .

12. Засади державної антикорупційної політики в Україні (Антикорупційна стратегія) на 2020-2024 роки : веб-сайт Національного агенства 3 питань запобігання корупції. URL: https://nazk.gov.ua/ wp-content/uploads/2020/09/Antykoruptsijna-strategiya-na-2020-2024-roky- 
za-rezultatamy-publichnyh-obgovoren-16.09.2020.pdf (дата

звернення 20.12.2021).

13. Державна митна служба. За 2020 рік працівники Держмитслужби виявили порушень митних правил на 2,6 млрд грн : веб-сайт. URL: https://customs.gov.ua/en/news/novini-20/post/za-2020-rik-pratsivnikiderzhmitsluzhbi-viiavili-porushen-mitnikh-pravil-na-26-mlrd-grn-296 (дата звернення 20.12.2021).

DOI https://doi.org/10.30525/978-9934-26-179-4-35

\title{
ЩОДО ОКРЕМИХ ПИТАНЬ ПРАВОВОГО РЕГУЛЮВАННЯ ЗБОРУ ЗА МІСЦЯ ДЛЯ ПАРКУВАННЯ ТРАНСПОРТНИХ ЗАСОБІВ
}

\author{
Татаренко О. Ю. \\ аспірант кафедри фінансового права \\ Національний юридичний університет імені Ярослава Мудрого \\ м. Харків, Украӥна
}

Зобовязуючий характер податкових відносин та різноманітність обов'язкових платежів податкового характеру, зумовлюють потребу у дослідженні умов набуття статусу платника збору за місця для паркування та передумов виникнення обов'язку зі сплати цього обов'язкового платежу.

Суб'єкти вступаючи у конкретні правовідносини при реалізації своїх прав і обов'язків, набувають нових якостей - вони стають суб'єктами (учасниками) правовідносин, зберігаючи якості набуті до вступу у правовідносин. Основним змістом податкових правовідносин є обов'язок платника податків, внести суму до відповідного бюджету, а обов'язок компетентного органу - забезпечити сплату податків $[1$, c.71. 333]. Умови за яких особа може бути визнана в якості суб'єкта (учасника) податкових відносин 3 приводу оподаткування збором за місця для паркування транспортних засобів, законодавчо регламентовані. Такі умови, пов'язуються 3 приналежністю до відповідного кола осіб та настанням обставин, які $є$ визначальним при встановленні податкового обов'язку особи щодо сплати збору за місця для паркування транспортних засобів. 